\title{
Seed germination of Brazilian Aldama species (Asteraceae) ${ }^{1}$
}

\author{
Aline Bertolosi Bombo², Tuane Santos de Oliveira², Beatriz Appezzato-da- \\ Glória $^{2^{*}}$, Ana Dionísia da Luz Coelho Novembre ${ }^{3}$
}

\begin{abstract}
Brazilian samples from the Aldama genus (Asteraceae) could not propagate vegetatively despite their thickened underground system; thus, this study on sexual propagation is critical given the lack of data on reproductive strategies for such species. The aim for this research was to assess the optimal temperature for Aldama arenaria, A. filifolia, A. linearifolia, A. robusta and A. trichophylla seed germination. Seed germination was evaluated at the constant temperatures 20,25 and $30{ }^{\circ} \mathrm{C}$ and the alternating temperatures $15-35,20-30$ and $20-35^{\circ} \mathrm{C}$ with an 8-h daily photoperiod, using fluorescent-lamp. The ungerminated seeds were evaluated for embryo viability. The A. filifolia seed health was also evaluated. The optimal temperatures for germination are 20 and $25^{\circ} \mathrm{C}$ for Aldama arenaria, A. filifolia, A. robusta and A. trichophylla seeds and $20^{\circ} \mathrm{C}$ for $A$. linearifolia seeds. The alternating temperature $15-35^{\circ} \mathrm{C}$ is not recommended for germinating seeds from these species. The six fungi taxa studied herein did not affect $A$. filifolia seed germination.
\end{abstract}

Index terms: Compositae, sexual propagation, Viguiera, cerrado.

\section{Germinação de sementes de espécies brasileiras de Aldama (Asteraceae)}

\begin{abstract}
RESUMO - Amostras de espécies brasileiras do gênero Aldama (Asteraceae) não têm capacidade de se propagar vegetativamente, apesar do seu sistema subterrâneo espessado; assim, esse estudo da propagação sexuada é importante, devido à falta de informações sobre as estratégias de reprodução dessas espécies. O objetivo da pesquisa foi determinar a faixa ideal de temperatura para a germinação das sementes de Aldama arenaria, A. filifolia, A. linearifolia, Aldama robusta e A. trichophylla. A germinação das sementes foi avaliada em temperaturas constantes de 20,25 e $30^{\circ} \mathrm{C}$ e alternadas de $15-35,20-30$ e $20-35^{\circ} \mathrm{C}$ sob fotoperíodo diário de $8 \mathrm{~h}$, sob lâmpada fluorescente. As sementes não germinadas foram avaliadas quanto à viabilidade do embrião. A sanidade das sementes de $A$. filifolia também foi avaliada. As temperaturas ideais para a germinação das sementes de Aldama arenaria, A. filifolia, A. robusta e A. trichophylla são 20 e $25^{\circ} \mathrm{C}$ e, para as de A. linearifolia é $20^{\circ} \mathrm{C}$. A temperatura alternada de $15-35^{\circ} \mathrm{C}$ não é recomendada para a germinação das sementes dessas espécies. Os seis táxons de fungos que foram determinados não influenciam na germinação das sementes de A. filifolia.
\end{abstract}

Termos para indexação: Compositae, propagação sexuada, Viguiera, cerrado.

\section{Introduction}

The genus Aldama La Llave belongs to the Asteraceae family and includes South American species previously classified as Viguiera sensu lato (Schilling and Panero, 2011). Brazilian species from this genus occur mainly in the Cerrado regions in climates that have dry winters (Magenta et al., 2010), and these species are most often observed under such conditions that may be related to the type of thickened underground system, which supports the plants' water needs during dormancy (Zaidan and Carreira, 2008; Magenta et al., 2010) and is essential for regenerating the vegetative aerial portions (Oliveira et al., 2013;

${ }^{1}$ Submitted on 02/18/2015. Accepted for publication on 07/06/2015.

${ }^{2}$ Departamento de Ciências Biológicas, USP/ESALQ, Caixa Postal 9, 13418-900 - Piracicaba, SP, Brasil.
Bombo et al., 2014). The thickened underground systems, which can bear buds, were observed in other Asteraceae species, and these systems may be morphologically diverse, such as xylopodia, rhizophores, root buds and diffuse underground systems (Vilhalva and Appezzato-da-Glória, 2006; Hayashi and Appezzato-da-Glória, 2007; Appezzato-da-Glória et al., 2008; Appezzato-da-Glória and Cury, 2011). However, it has been observed that some species cannot propagate vegetatively even bearing a thickened underground system, and the sexual reproduction ensures maintenance of the species (Cury et al., 2010). The underground system for Brazilian species from the Aldama genus is characterized by a

${ }^{3}$ Departamento de Produção Vegetal, USP/ESALQ, Caixa Postal 9, 13418-900 - Piracicaba, SP, Brasil.

*Corresponding author:< bagloria@usp.br> 
xylopodium emitting tuberous roots (Oliveira et al., 2013; Bombo et al., 2014); therefore, these species do not use vegetative propagation as a form of reproduction.

Few studies have investigated seed germination for Brazilian Asteraceae species (Ferreira et al., 2001; Gomes and Fernandez, 2002; Velten and Garcia, 2005; Garcia et al., 2006; Cury et al., 2010), and about the propagation strategies of Brazilian Aldama species. Germination behavior has only been reported for Aldama robusta (Gardner) E.E.Schill. \& Panero (= Viguiera robusta), and for this species the germination was characterized as slow process (Ruggiero and Zaidan, 1997).

Research on the phytochemistry of several species of Aldama genus have highlighted the pharmacological importance of this genus (Costa et al., 1996; Marquina et al., 2001; Spring et al., 2003; Ambrosio et al., 2004); therefore, reproductive studies on plant species are important for proposing strategies to ensure a sustainable development (Gomes and Fernandez, 2002) and conservation of such species, since Aldama filifolia and A. linearifolia are on the red list as species threatened with extinction (Brasil, 2014). Thereby, the aim of this research was to study germination and determine the optimal temperature for five species from the Aldama genus.

\section{Material and Methods}

\section{Cypsela collection and storage}

According to Marzinek et al. (2008), Asteraceae plants have cypsela-type fruits. Seeds could not be removed from the fruits in that species; thus, the propagating unit that comprised the fruit and seed (referred as the seed in the text) was evaluated in the experiments.

Cypselas used for germination tests were collected from plants of natural populations of Aldama arenaria (Baker) E.E.Schill. \& Panero (= Viguiera arenaria), A. filifolia (Sch.Bip. ex Baker) E.E.Schill. \& Panero (=V. filifolia), $A$. linearifolia (Chodat) E.E.Schill. \& Panero (= V. linearifolia), Aldama robusta (Gardner) E.E.Schill. \& Panero ( $=V$. robusta) and A. trichophylla (Dusén) Magenta $(=V$. trichophylla) in Cerrado in Itirapina - Estação Ecológica de Itirapina, SP, Brazil, Alto Paraíso de Goiás - Goiás (GO), Ponta Porã Mato Grosso do Sul (MS), Altinópolis - São Paulo (SP) and Palmeira - PR, respectively, between April and November 2010, along the fruiting period for each species. The plants were identified by an expert on this genus and included in the ESA herbarium, 'Luiz de Queiroz' College of Agriculture (Escola Superior de Agricultura 'Luiz de Queiroz') under the numbers $111847,111848,113164,114255$ and 111850.

The entire capitula were collected, spread on paper, maintained at $22{ }^{\circ} \mathrm{C}$ until dried and stored for three months in paper bags at the same temperature.

\section{Experiment set-up and seed germination monitoring}

Seeds were manually removed from the capitula, homogenized in a tray and visually selected in order to eliminate the wilted or predated seeds, which were discarded, and just the apparently undamaged and healthy ones were manually selected for germination test. However, it was impossible to assess whether they contained an embryo based on their external physical appearance or by pressure.

Five replicates with at least 16 seeds each were used for each temperature evaluated (See Table 1). The amount of seeds in each repetition varied among the species because it was determined according to the availability of seeds at collection, since these seeds were obtained from natural populations. However, the amount was always the same among the replicates within a species. The seeds were randomly distributed on two sheets of blotting paper, hydrated with $13 \mathrm{~mL}$ of distilled water and packed in previously sterilized transparent plastic boxes $(13 \times 13 \times 3.5 \mathrm{~cm})$. The boxes were distributed into six germination chambers (Marconi brand, MA 402 model) at the constant temperatures of 20,25 and $30^{\circ} \mathrm{C}$ with a 8 -h daily photoperiod and alternating temperatures 15 $35,20-30$ and $20-35{ }^{\circ} \mathrm{C}$, with a 8 -h daily photoperiod in the top temperature, using fluorescent-lamp lighting with 40.32 mmol. $\mathrm{m}^{-2} \mathrm{~s}^{-1}$ irradiation.

The test was performed until no germination was observed anymore, and this occurred after 32 days. When it was necessary, the paper was moistened to ensure the water supply to the seeds during the test. The seeds were considered germinated when they originated normal seedlings with two cotyledons, hypocotyl and primary root and the nongerminated seeds were also counted (Brasil, 2009).

With the obtained results, the germination speed index (GSI, using the formula proposed by Maguire (1962), mean germination time (Laboriau, 1983) and germination percentage were calculated for each species. The values generated were assessed through statistical analysis for the normal distribution using the Kolmogorov-Smirnov test. The data were transformed into an $\operatorname{arcsen} \sqrt{\mathrm{x} / 100}$ and into the $\sqrt{\mathrm{x}+0.5}$ when the parameter values were equal to zero. Next, an analysis of variance was used for the results, and the means were compared through the Tukey test $(\mathrm{p}<0.05)$ using the Statistical Analysis System (SAS) software (Sas Institute, 2003). 
Table 1. Germination (G, \%), germination speed index (GSI) and mean germination time (MT, days) for Aldama arenaria, A. filifolia, A. linearifolia, A. robusta and A. trichophylla seeds evaluated at the constant temperatures 20,25 and $30{ }^{\circ} \mathrm{C}$ with a 8 -h daily photoperiod and the alternating temperatures $15-35,20-30$ and $20-35^{\circ} \mathrm{C}$ with a 8 -h daily photoperiod in the upper temperature. Values with the same letter in the same column do not differ statistically, within each species.

\begin{tabular}{|c|c|c|c|c|}
\hline Species & Temperature $\left({ }^{\circ} \mathrm{C}\right)$ & $\mathrm{G}(\%)$ & GSI & MT (days) \\
\hline \multirow{6}{*}{$\begin{array}{l}\text { Aldama arenaria } \\
\qquad(\mathrm{n}=600)\end{array}$} & 20 & $92 \mathrm{a}$ & $2.70 \mathrm{bc}$ & $7.24 \mathrm{bc}$ \\
\hline & 25 & $88 \mathrm{ab}$ & $3.81 \mathrm{a}$ & $5.01 \mathrm{a}$ \\
\hline & 30 & $74 \mathrm{ab}$ & $2.69 \mathrm{bc}$ & $6.29 \mathrm{abc}$ \\
\hline & $15-35$ & $73 \mathrm{~b}$ & $1.52 \mathrm{~d}$ & $10.86 \mathrm{~d}$ \\
\hline & $20-30$ & $82 \mathrm{ab}$ & $2.93 \mathrm{~b}$ & $6.07 \mathrm{ab}$ \\
\hline & $20-35$ & $71 \mathrm{~b}$ & $1.95 \mathrm{~cd}$ & $8.02 \mathrm{c}$ \\
\hline \multirow{6}{*}{$\begin{array}{l}\text { Aldama filifolia } \\
\qquad(\mathrm{n}=750)\end{array}$} & 20 & $50 \mathrm{a}$ & $1.14 \mathrm{ab}$ & $11.81 \mathrm{a}$ \\
\hline & 25 & $48 \mathrm{a}$ & $1.29 \mathrm{a}$ & $10.05 \mathrm{a}$ \\
\hline & 30 & $33 \mathrm{bc}$ & $0.76 \mathrm{c}$ & $12.71 \mathrm{ab}$ \\
\hline & $15-35$ & $8 \mathrm{~d}$ & $0.10 \mathrm{~d}$ & $23.73 \mathrm{c}$ \\
\hline & $20-30$ & $41 \mathrm{ab}$ & $0.89 \mathrm{bc}$ & $12.63 \mathrm{ab}$ \\
\hline & $20-35$ & $22 \mathrm{c}$ & $0.34 \mathrm{~d}$ & $17.40 \mathrm{~b}$ \\
\hline \multirow{6}{*}{$\begin{array}{l}\text { Aldama linearifolia } \\
\qquad(\mathrm{n}=705)\end{array}$} & 20 & $29 a$ & $0.49 \mathrm{a}$ & $14.73 \mathrm{a}$ \\
\hline & 25 & $22 \mathrm{a}$ & $0.43 \mathrm{ab}$ & $12.79 \mathrm{a}$ \\
\hline & 30 & $13 \mathrm{a}$ & $0.23 \mathrm{ab}$ & $12.55 \mathrm{a}$ \\
\hline & $15-35$ & $17 \mathrm{a}$ & $0.21 \mathrm{~b}$ & $21.75 b$ \\
\hline & $20-30$ & $28 \mathrm{a}$ & $0.49 \mathrm{a}$ & $14.54 \mathrm{a}$ \\
\hline & $20-35$ & $20 \mathrm{a}$ & $0.34 \mathrm{ab}$ & $15.09 \mathrm{a}$ \\
\hline \multirow{6}{*}{$\begin{array}{l}\text { Aldama robusta } \\
\qquad(\mathrm{n}=480)\end{array}$} & 20 & $97 \mathrm{a}$ & $2.01 \mathrm{a}$ & $7.99 \mathrm{ab}$ \\
\hline & 25 & $95 \mathrm{ab}$ & $2.21 \mathrm{a}$ & $7.55 \mathrm{a}$ \\
\hline & 30 & $67 \mathrm{c}$ & $1.14 \mathrm{c}$ & $10.56 \mathrm{ab}$ \\
\hline & $15-35$ & $17 \mathrm{~d}$ & $0.12 \mathrm{~d}$ & $24.71 \mathrm{~d}$ \\
\hline & $20-30$ & $97 \mathrm{a}$ & $1.68 \mathrm{~b}$ & $10.96 \mathrm{~b}$ \\
\hline & $20-35$ & $85 \mathrm{bc}$ & $0.89 \mathrm{c}$ & $17.72 \mathrm{c}$ \\
\hline \multirow{6}{*}{$\begin{array}{l}\text { Aldama trichophylla } \\
\qquad(\mathrm{n}=750)\end{array}$} & 20 & $47 \mathrm{a}$ & $1.68 \mathrm{ab}$ & $7.30 \mathrm{a}$ \\
\hline & 25 & $54 \mathrm{a}$ & $2.54 \mathrm{a}$ & $5.85 \mathrm{a}$ \\
\hline & 30 & $34 a b$ & $1.49 \mathrm{~b}$ & $6.98 \mathrm{a}$ \\
\hline & $15-35$ & $50 \mathrm{a}$ & $1.26 \mathrm{~b}$ & $10.48 \mathrm{~b}$ \\
\hline & $20-30$ & $42 a b$ & $1.60 \mathrm{~b}$ & $7.22 \mathrm{a}$ \\
\hline & $20-35$ & $22 \mathrm{~b}$ & $0.77 \mathrm{~b}$ & $7.60 \mathrm{a}$ \\
\hline
\end{tabular}

\section{Evaluation of ungerminated seeds}

After the final evaluation, the seeds were kept under the same conditions for an additional 10-day period to ensure stabilization of the germination process. Thereafter, the nongerminated seeds were analyzed to verify the presence or absence of the embryo and its viability. For such analysis, a cross-sectional cut was done along the fruit just below the pappus insertion, and if the seed contained an embryo, it was removed and evaluated for viability through the tetrazolium test using the method reported by Cury et al. (2010) and the results expressed as the percentage of viable embryos.

\section{Seed health test}

During the experiment, the incidence of fungi was recorded just for seeds from Aldama filifolia species, and they were evaluated by the health test. Thus, 100 seeds were collected as described before, distributed on three sheets of filter paper soaked in water, placed in Petri dishes (25 seeds per plate) and maintained at $20{ }^{\circ} \mathrm{C}$ with a 12 -h daily photoperiod for seven days. Thereafter, the fungi were identified from the colonies and the results were expressed as the percentage of fungi.

\section{Results and Discussion}

\section{Seed germination}

The results of the germination tests for the five studied species (Table 1) indicated that all of them presented some 
germination percentage in all the tested temperatures. Among them, $A$. robusta, followed by $A$. arenaria, were the species with higher percentage of germination while $A$. linearifolia had the lowest performance at all the temperatures. The test also indicated that the constants temperatures $20,25^{\circ} \mathrm{C}$ and the alternating temperature $20-30{ }^{\circ} \mathrm{C}$ were the best treatments with the significantly higher percentage of germination in $A$. filifolia and A. robusta and $20,25,30^{\circ} \mathrm{C}$ and $20-30{ }^{\circ} \mathrm{C}$ in $A$. arenaria, while for $A$. trichophylla all the treatments responded at the same way, except the alternating temperature $20-35^{\circ} \mathrm{C}$, which presented significantly lower values of percentage of germination. A statistically significant difference was not found among the temperatures evaluated for A. linearifolia species.

The $15-35{ }^{\circ} \mathrm{C}$ and $20-35{ }^{\circ} \mathrm{C}$ alternating temperature produced significantly lower results of germination, GSI and mean time of germination for seeds of Aldama arenaria and A. filifolia; for A. robusta $15-35^{\circ} \mathrm{C}$ was not a good treatment for these parameters; the results for GSI and mean time of germination in $A$. linearifolia seeds were lower despite the statistically similar results for germination rate. For $A$. trichophylla seeds, the $20-35{ }^{\circ} \mathrm{C}$ alternating temperature significantly reduced the percentage of germination while 15$35^{\circ} \mathrm{C}$ reduced the speed of that process.

Aldama seeds germinated in a range of constant and alternating temperatures. This ability may have useful consequences, because at least some seeds will germinate, whatever the environmental conditions they are submitted (Silva et al., 2002). Moreover, seed germination studies on Asteraceae species (Ferreira et al., 2001; Gomes and Fernandez, 2002; Velten and Garcia, 2005; Garcia et al., 2006; Cury et al., 2010) indicate that different species germinate differently and respond to distincts alternating temperatures with variations in germination rates. The constant or alternating temperatures between 20 and $30{ }^{\circ} \mathrm{C}$ were most efficient despite the variation in optimal temperature for seed germination for the species studied. Albuquerque et al. (2003) reported that the seeds from certain medicinal species in the Cerrado typically germinate at the constant temperatures 25 or $30^{\circ} \mathrm{C}$, and Ruggiero and Zaidan (1997) had already indicated that $20-30{ }^{\circ} \mathrm{C}$ is the most suitable temperature for Aldama robusta (Vigueira robusta) seeds germination.

The study herein demonstrated that the lowest germination percentages were observed for temperatures which seed germination was slowest, except for A. trichophylla seeds. In the temperatures where the germination percentages were higher, the GSI values were also higher, and consequently, the mean germination times were lower. High GSI values and low mean germination times indicate fast germination, which is a typical feature of species that can be established in the environment as quickly as possible, under favorable conditions (Velten and Garcia, 2005).

Among the five species investigated here, Aldama arenaria, followed by $A$. trichophylla were the species whose seeds germinated faster, while $A$. linearifolia presented the slowest germination process. The mean time or speed germination are good indicators of the speed for occupying a territory by a species at a given environment, i.e., its ability to propagate in its habitat (Ferreira et al., 2001). Gomes and Fernandez (2002) also highlighted the importance of rapid germination for a species to be able to recover degraded areas or occupy an environment. As proposed by Ferreira et al. (2001), species may be classified according to their seed germination speed: at temperatures with the highest germination rates, Aldama arenaria, A. trichophylla and $A$. robusta seeds were classified as intermediate germination, while $A$. filifolia and A. linearifolia seeds have slow germination. Such observations may explain the presence of the reduced populations of Aldama species studied here, which were observed specially on the sides of highways whose areas were often invaded by exotic grass that hamper seed germination and seedling establishment.

\section{Evaluation of ungerminated seeds}

The evaluation herein showed that the percentages for Aldama arenaria, A. robusta, A. filifolia and A. trichophylla seeds without embryos were 7, 8, 23 and $21 \%$, respectively. The highest percentage of seeds without embryos $(67 \%)$ was observed for Aldama linearifolia species. Dead seeds accounted for $6 \%$ of the seeds in Aldama linearifolia, $7 \%$ in A. arenaria and A. robusta, $32 \%$ in A. filifolia and $27 \%$ in $A$. trichophylla (Table 2).

The abnormal seedling morphology, which accounted for 5\% seedlings in A. arenaria, 9\% in A. filifolia, 5\% in $A$. linearifolia, 3\% in A. robusta and $10 \%$ in A. trichophylla (Table 2), was another factor that affected the germination results, in addition to the absent of embryos and dead seeds. The highest number of abnormal seedlings was observed under the constant temperature $30{ }^{\circ} \mathrm{C}$ and the alternating temperature $15-35$ and $20-35^{\circ} \mathrm{C}$ in A. arenaria, A. filifolia and $A$. trichophylla. In $A$. robusta the alternating temperature $15-35^{\circ} \mathrm{C}$ and in $A$. linearifolia the constant temperature $20^{\circ} \mathrm{C}$ produced lower values of abnormal seedlings.

The highest percentages of viable seeds that do not germinated was observed under the alternating temperature 15-35 ${ }^{\circ} \mathrm{C}$, which was the less efficient condition for seed germination in Aldama arenaria along with $20-35{ }^{\circ} \mathrm{C}, \mathrm{A}$. filifolia, A. linearifolia and $A$. robusta species, while, for $A$. trichophylla, $20-35{ }^{\circ} \mathrm{C}$ was the least efficient temperature. 
Although some species require daily temperature fluctuations to germinate (Silva et al., 2002), the observations here indicated that these two alternating temperatures are not recommended for germination in Aldama species, and it may even delay the process, which would explain the viable embryos in the ungerminated seeds.

Table 2. Analysis for ungerminated seeds or germinated seeds that produced abnormal seedlings for Aldama arenaria, A. filifolia, A. linearifolia, A. robusta and A. trichophylla. Percentage of abnormal seedlings, viable seeds, dead seeds and seeds without embryos. Values with the same letter in the same column do not differ statistically, within each species.

\begin{tabular}{|c|c|c|c|c|c|}
\hline \multirow{2}{*}{ Species } & \multirow{2}{*}{ Temperature $\left({ }^{\circ} \mathrm{C}\right)$} & \multirow{2}{*}{ Abnormal seedlings (\%) } & \multicolumn{3}{|c|}{ Ungerminated seeds $(\%)$} \\
\hline & & & Viable & Dead & Seed without embryos \\
\hline \multirow{6}{*}{ Aldama arenaria } & 20 & $0 \mathrm{c}$ & $0 \mathrm{~b}$ & $3 \mathrm{a}$ & $5 \mathrm{a}$ \\
\hline & 25 & $1 \mathrm{bc}$ & $0 \mathrm{~b}$ & $6 \mathrm{a}$ & $5 \mathrm{a}$ \\
\hline & 30 & $14 \mathrm{a}$ & $0 \mathrm{~b}$ & $9 \mathrm{a}$ & $3 \mathrm{a}$ \\
\hline & $15-35$ & $4 a b c$ & $6 \mathrm{a}$ & $9 \mathrm{a}$ & $8 \mathrm{a}$ \\
\hline & $20-30$ & $1 \mathrm{bc}$ & $0 \mathrm{~b}$ & $8 \mathrm{a}$ & $9 \mathrm{a}$ \\
\hline & $20-35$ & $9 \mathrm{ab}$ & $0 \mathrm{~b}$ & $7 \mathrm{a}$ & $13 \mathrm{a}$ \\
\hline \multirow{6}{*}{ Aldama filifolia } & 20 & $0 \mathrm{c}$ & $0 \mathrm{~b}$ & $24 \mathrm{a}$ & $26 \mathrm{ab}$ \\
\hline & 25 & $4 \mathrm{bc}$ & $0 \mathrm{~b}$ & $33 \mathrm{a}$ & $15 \mathrm{~b}$ \\
\hline & 30 & $11 \mathrm{ab}$ & $1 \mathrm{~b}$ & $33 \mathrm{a}$ & $22 \mathrm{ab}$ \\
\hline & $15-35$ & $26 \mathrm{a}$ & $10 \mathrm{a}$ & $42 \mathrm{a}$ & $14 \mathrm{~b}$ \\
\hline & $20-30$ & $5 \mathrm{bc}$ & $1 \mathrm{~b}$ & $27 \mathrm{a}$ & $26 \mathrm{ab}$ \\
\hline & $20-35$ & $12 \mathrm{ab}$ & $2 \mathrm{~b}$ & $28 \mathrm{a}$ & $36 \mathrm{a}$ \\
\hline \multirow{6}{*}{ Aldama linearifolia } & 20 & $1 \mathrm{~b}$ & $0 \mathrm{~b}$ & $8 \mathrm{a}$ & $62 \mathrm{a}$ \\
\hline & 25 & $3 a b$ & $0 \mathrm{~b}$ & $3 \mathrm{a}$ & $72 \mathrm{a}$ \\
\hline & 30 & $5 \mathrm{ab}$ & $0 \mathrm{~b}$ & $11 \mathrm{a}$ & $71 \mathrm{a}$ \\
\hline & $15-35$ & $10 \mathrm{a}$ & $3 \mathrm{a}$ & $7 \mathrm{a}$ & $63 \mathrm{a}$ \\
\hline & $20-30$ & $3 a b$ & $0 \mathrm{~b}$ & $4 \mathrm{a}$ & $65 \mathrm{a}$ \\
\hline & $20-35$ & $8 \mathrm{ab}$ & $0 \mathrm{~b}$ & $5 \mathrm{a}$ & $67 \mathrm{a}$ \\
\hline \multirow{6}{*}{ Aldama robusta } & 20 & $0 \mathrm{~b}$ & $0 \mathrm{~b}$ & $0 \mathrm{~b}$ & $3 b$ \\
\hline & 25 & $0 \mathrm{~b}$ & $0 \mathrm{~b}$ & $0 \mathrm{~b}$ & $5 \mathrm{ab}$ \\
\hline & 30 & $0 \mathrm{~b}$ & $3 b$ & $19 \mathrm{a}$ & $11 \mathrm{ab}$ \\
\hline & $15-35$ & $18 \mathrm{a}$ & $23 \mathrm{a}$ & $25 \mathrm{a}$ & $17 \mathrm{a}$ \\
\hline & $20-30$ & $0 \mathrm{~b}$ & $0 \mathrm{~b}$ & $0 \mathrm{~b}$ & $3 \mathrm{~b}$ \\
\hline & $20-35$ & $3 \mathrm{~b}$ & $1 \mathrm{~b}$ & $0 \mathrm{~b}$ & $11 \mathrm{ab}$ \\
\hline \multirow{6}{*}{ Aldama trichophylla } & 20 & $2 \mathrm{c}$ & $0 \mathrm{a}$ & $30 \mathrm{a}$ & $21 \mathrm{ab}$ \\
\hline & 25 & $2 \mathrm{c}$ & $0 \mathrm{a}$ & $21 \mathrm{a}$ & $23 \mathrm{ab}$ \\
\hline & 30 & $17 \mathrm{ab}$ & $0 \mathrm{a}$ & $37 \mathrm{a}$ & $12 \mathrm{~b}$ \\
\hline & $15-35$ & $9 a b c$ & $2 \mathrm{a}$ & $26 \mathrm{a}$ & $13 \mathrm{~b}$ \\
\hline & $20-30$ & $6 \mathrm{bc}$ & $0 \mathrm{a}$ & $21 \mathrm{a}$ & $31 \mathrm{a}$ \\
\hline & $20-35$ & $22 \mathrm{a}$ & $0 \mathrm{a}$ & $30 \mathrm{a}$ & $26 \mathrm{ab}$ \\
\hline
\end{tabular}

Several factors may affect the seed germination rate, including the decrease in seed viability during storage (Sassaki et al., 1999; Gomes and Fernandez, 2002), the number of seeds without embryos (Sassaki et al., 1999; Velten and Garcia, 2005; Cury et al., 2010) and the collection of immature seeds (Albuquerque et al., 2003). The number of seeds without embryo in the species studied herein, excluding Aldama linearifolia seeds, was relatively low when compared with other Asteraceae species (Sassaki et al., 1999; Velten and Garcia, 2005; Cury et al., 2010). For example, the higher percentage of seeds without embryos in Chresta sphaerocephala DC. (85\%) compared with Lessingianthus bardanoides (Less.) H. Rob. (54\%) is related to the ability of $C$. sphaerocephala to propagate vegetatively through root buds, while L. bardanoides representatives bear a xylopodium and the species propagates only by seeds (Cury et al., 2010). For Aldama species studied herein, which have xylopodium as underground organ (Oliveira et al., 2013; Bombo et al., 2014), the vegetative propagation is not common, and this could be related to the low percentage of seeds without embryos in 
such species. In turn, the high number of empty seed in $A$. linearifolia is related to the maturation degree of the seeds, since this species has the same sort of underground organ.

\section{Seed health test}

The results from the seed health evaluation for Aldama filifolia allowed identification of six fungi taxa associated with its seeds. Alternaria alternata were found in $98 \%$ of seeds, Cladosporium sp. in 90\%, Fusarium sp. in 9\%, Alternaria sp. in 1\%, Phoma sp. in 1\% and Nigrospora sp. in $1 \%$. Fungi have been reported in seeds for several species, including Asteraceae family representatives (Lima et al., 2003; Reis et al., 2006). Fungal development during germination may increase levels of infected or dead seeds in addition to diseased seedlings; thus, seed contamination may affect their physiological quality and, in certain cases, inhibit the germination process (Castellani et al., 1996; Botelho et al., 2008). Although fungal infestation was observed for all treatments analyzed, the increase in abnormal seedlings coincided with the temperature which provided the lowest germination rate. Therefore, such infestation seems not to have affected seed germination process of the studied species, as already observed by Oliveira et al. (2003) for Peltophorum dubium (Sprengel) Taubert (Fabaceae) seeds.

\section{Conclusions}

Considering the levels of germinated seeds, germination speed index and mean germination time simultaneously, the best temperatures for seed germination are the constant temperatures $20^{\circ} \mathrm{C}$ and $25^{\circ} \mathrm{C}$ for Aldama filifolia, A. robusta and A. trichophylla, $20{ }^{\circ} \mathrm{C}$ for $A$. areanaria and for $A$. linearifolia just the alternating temperature $15-35{ }^{\circ} \mathrm{C}$ is not recommended. However, the five species responded well to almost all treatments used and other temperature ranges may also be used. The alternating temperature $15-35{ }^{\circ} \mathrm{C}$ is not recommended for such species, except to $A$. trichophylla, for which $20-35{ }^{\circ} \mathrm{C}$ is the temperature not recommend.

\section{Acknowledgments}

We thank The National Council for Scientific and Technological Development $(\mathrm{CNPq})$ for grants (302776/2010-9) and the São Paulo Council for Research (FAPESP) (Thematic Project Proc. no 2010/51454-3, Proc. no. 2010/01931-0) for providing financial support and grants to the first author. We are also grateful to Professor Mara Angelina Galvão Magenta for plant identification, the coordinator of the Parque Nacional da Chapada dos Veadeiros, GO, Brazil and the coordinator of the Estação Ecológica de Itirapina, SP, Brazil for granting permission and facilities to collect plant material for this study. Finally, we thank the Seed Pathology Laboratory, Department of Plant Pathology and Nematology, 'Luiz de Queiroz' College of Agriculture/University of São Paulo, in which the seed health test was performed.

\section{References}

ALBUQUERQUE, M.C.F.; COELHO, M.F.B.; ALBRECTH, J.M.F. Germinação de sementes de espécies medicinais do Cerrado. In: COELHO, M.F.B.; COSTA JÚNIOR, P.; DOMBROSKI, J.L.D. (Ed.). Diversos olhares em etnobiologia, etnoecologia e plantas medicinais. Cuiabá UNICEN, 2003, p. 157-181.

AMBROSIO, S.R.; SCHORR, K.; COSTA, F.B. Terpenoids of Viguiera arenaria (Asteraceae). Biochemical Systematics and Ecology, v.32, p.221-224, 2004. http://www.sciencedirect.com/science/article/pii/ S030519780300139X

APPEZZATO-DA-GLÓRIA, B.; CURY, G. Morpho-anatomical features of underground systems in six Asteraceae species from the Brazilian Cerrado. Anais da Academia Brasileira de Ciências, v.83, n.3, p.981-992, 2011. http://www. scielo.br/scielo.php?pid=S0001-37652011000300017\&script=sci_arttext

APPEZZATO-DA-GLÓRIA, B.; HAYASHI, A.H.; CURY, G.; SOARES, M.K.M.; ROCHA, R. Ocurrence of secretory structures in underground systems of seven Asteraceae species. Botanical Journal of the Linnean Society, v.157, n.4, p.789-796, 2008. http://onlinelibrary.wiley.com/ doi/10.1111/j.1095-8339.2008.00823.x/abstract

BOMBO, A.B.; OLIVEIRA, T.S.; OLIVEIRA, A.S.S.; REHDER, V.L.G.; APPEZZATO-DA-GLÓRIA, B. Anatomy and essential oil composition of the underground systems of three species of Aldama La Llave (Asteraceae). The Journal of the Torrey Botanical Society, v.141, n.2, p.115-125, 2014 http://www.bioone.org/doi/abs/10.3159/TORREY-D-12-00053.1

BOTELHO, L.D.S.; MORAES, M.H.D.; MENTEN, J.O.M. Fungos associados às sementes de ipê-amarelo (Tabebuia serratifolia) e ipê-roxo (Tabebuia impetiginosa): incidência, efeito na germinação e transmissão para as plântulas. Summa Phytopathologica,v.34,n.4,p.343-348,2008. http://www. scielo.br/scielo.php?script=sci_arttext\&pid=S0100-54052008000400008

BRASIL. Ministério da Agricultura, Pecuária e Abastecimento. Regras para análise de sementes. Ministério da Agricultura, Pecuária e Abastecimento. Secretaria de Defesa Agropecuária. Brasília: MAPA/ACS, 2009. 395p. http:// www.agricultura.gov.br/arq_editor/file/2946_regras_analise_sementes.pdf

BRASIL. Ministério do Meio Ambiente. 17 de dezembro de 2014. Diário oficial da união, Brasília, DF, 18 dez. 2014, p. 110. Portaria no 443 Seção I.

CASTELLANI, E.D.; SILVA. A.; BARRETO, M.; AGUIAR, I.B. Influência do tratamento químico na população de fungos e na germinação de sementes de Bauhinia variegata L. var. Variegata. Revista Brasileira de Sementes, v.18, n.1, p.41-44, 1996. http://www.abrates.org.br/revista/artigos/1996/ v18n1/artigo07.pdf

COSTA, F.B.; VICHNEWSKI, W.; HERZ, W. Constituents of Viguiera aspillioides and V. robusta. Biochemical Systematics and Ecology, v.24, n.6, p.585-587, 1996. http://www.sciencedirect.com/science/article/ pii/0305197896000579 
CURY, G.; NOVEMBRE, A.D.L.C.; APPEZZATO-DA-GLÓRIA, B. Seed germination of Chresta sphaerocephala DC. and Lessingianthus bardanoides (Less.) H. Rob. (Asteraceae) from Cerrado. Brazilian Archives of Biology and Technology, v.53, n.6, p.1299-1308, 2010. http://www.scielo.br/scielo. php?pid=S1516-89132010000600006\&script=sci_arttext

FERREIRA, A.G.; CASSOL, B.; ROSA, S.G.T.; SILVEIRA, T.S.; STIVAL, A.L.; SILVA, A.A. Germinação de sementes de Asteraceae nativas no Rio Grande do Sul, Brasil. Acta Botanica Brasilica, v.15, n.2, p.231-242, 2001. http://www.sciencedirect.com/science/article/pii/0305197896000579

GARCIA, L.C.; BARROS, F.V.; LEMOS FILHO, J.P. Comportamento germinativo de duas espécies de canga ferrífera: Baccharis retusa DC. (Asteraceae) e Tibouchina multiflora Cogn. (Melastomataceae). Acta Botanica Brasilica, v.20, n.2, p.443-448, 2006. http://www.scielo.br/scielo. php?pid=S0102-33062006000200019\&script $=$ sci_abstract\&tlng=pt

GOMES, V.; FERNANDEZ, G.W. Germinação de aquênios de Baccharis dracunculifolia D.C. (Asteraceae). Acta Botanica Brasilica, v.16, n.4, p.421-427, 2002. http://www.scielo.br/scielo.php?script=sci_ arttext\&pid=S0102-33062002000400005

HAYASHI, A.H.; APPEZZATO-DA-GLÓRIA, B. Anatomy of the Underground System in Vernonia grandiflora Less. and $V$. brevifolia Less. (Asteraceae). Brazilian Archives of Biology and Technology, v.50, n.6, p.979-988, 2007. http://www.scielo.br/scielo.php?script=sci arttext\&pid=S1516-89132007000700009

LABORIAU, L.G. A germinação de sementes. Washington: Secretaria Geral da OEA, 1983, 171p.

LIMA, M.L.P.; REIS, A.; LOPES, C.A. Patogenicidade de Alternaria cichorii sobre espécies da família Asteraceae no Brasil. Fitopatologia Brasileira, v.28, n.6, p.682-685, 2003. http://www.scielo.br/pdf/fb/v28n6/a16v28n6.pdf

MAGENTA, M.A.G.; NUNES, A.D.; MENDONÇA, C.B.F.; GONÇALVES-ESTEVES, V. Palynotaxonomy of Brazilian Viguiera (Asteraceae) species. Boletin de la Sociedad Argentina de Botanica, v.45, n.3-4, p.285-299, 2010. http://www.scielo.org.ar/scielo.php?script=sci arttext\&pid=S1851-23722010000200008

MAGUIRE, J.D. Speed of germination-aid in selection and evaluation for seedling emergence and vigor. Crop Science, v.2, n.2, p.176-177, 1962. https://www.crops.org/publications/cs/pdfs/2/2/CS0020020176

MARQUINA, S.; MALDONADO, N.; GARDUÑO-RAMÍREZ, M.L.; ARANDA, E. VILLARREAL, M.L.; NAVARRO, V.; BYE, R.; DELGADO, G.; ALVAREZ, L. Bioactive oleanolic acid saponins and other constituents from the roots of Viguiera decurrens. Phytochemistry, v.56, p.93-97, 2001. http://www.sciencedirect.com/science/article/pii/S0031942200002831

MARZINEK, J.; DE-PAULA, O.C.; OLIVEIRA, D.M.T. Cypsela or achene? Refining terminology by considering anatomical and historical factors. Revista Brasileira de Botânica, v.31, n.3, p.549-553, 2008. http://www. scielo.br/scielo.php?pid=S0100-84042008000300018\&script=sci_arttext

OLIVEIRA, T.; BOMBO, A.B.; APPEZZATO-DA-GLORIA, B. Anatomy of vegetative organs with an emphasis on the secretory structures of two species of Aldama (Asteraceae - Heliantheae). Botany, v.91, n.6, p.335-342, 2013. http:// www.nrcresearchpress.com/doi/abs/10.1139/cjb-2012-0271\#.U17YR_msiSo
OLIVEIRA, L.M.; DAVIDE; A.C.; CARVALHO, M.L.O. Avaliação de métodos para quebra da dormência e para a desinfestação de sementes de canafístula (Peltophorum dubium) (Sprengel) Taubert. Revista Árvore, v.27, n.5, p.597-603, 2003. http://www.redalyc.org/articulo.oa?id=48827501

REIS, A.; SATELIS, J.F.; PEREIRA, R.S.; NASCIMENTO, W.M. Associação de Alternaria dauci e A. alternata com sementes de coentro e eficiência do tratamento químico. Horticultura Brasileira, v.24, n.1, p.107-111, 2006. http:// www.scielo.br/scielo.php?pid=S0102-05362006000100022\&script $=$ sci_ abstract\&tlng $=\mathrm{pt}$

RUGGIERO, P.G.C.; ZAIDAN, L.B.P. Estudos de desenvolvimento de Viguiera robusta Gardn., uma Asteraceae do Cerrado. Revista Brasileira Botânica, v.20, n.1, p.1-9, 1997. http://www.scielo.br/scielo.php?pid=S0100$84041997000100001 \&$ script $=$ sci_arttext

SAS INSTITUTE. Sas System: SAS/STAT version 9.1 (software). Cary, 2003.

SASSAKI，R.M.; RONDON，J.N.; ZAIDAN, L.B.P.; FELIPPE，G.M Germination of seeds from herbaceous plants artificially stored in Cerrado soil. Revista Brasileira de Biologia, v.59, n.2, p.271-279, 1999. http://www. scielo.br/scielo.php?pid=S0034-71081999000200011\&script=sci_arttext

SCHILLING, E.E.; PANERO, J.L. A revised classification os subtribe Helianthinae (Asteraceae: Heliantheae) II. Derived lineages. Botanical Journal of the Linnean Society, v.167,p.311-331, 2011. http://onlinelibrary. wiley.com/doi/10.1111/j.1095-8339.2011.01172.x/abstract

SILVA, L.M.M.; RODRIGUES, T.J.D.; AGUIAR, I.B. Efeito da luz e da temperatura na germinação de sementes de aroeira (Myracrodruon urundeuva Allemão). Revista Árvore, v.26, n.6, p.691-697, 2002. http://www.scielo.br/ $\mathrm{pdf} / \mathrm{rarv} / \mathrm{v} 26 \mathrm{n6} / \mathrm{a} 06 \mathrm{v} 26 \mathrm{n} 6 . \mathrm{pdf}$

SPRING, O.; ZIPPER, R.; CONRAD, J.; VOGLER, B.; KLAIBER, I.; COSTA, F.B. Sesquiterpene lactones from glandular trichomes of Viguiera radula (Heliantheae; Asteraceae). Phytochemistry, v.62, p.1185-1189, 2003. http://www.sciencedirect.com/science/article/pii/S0031942202007471

VELTEN, S.B.; GARCIA, Q.S. Efeitos da luz e da temperatura na germinação de sementes de Eremanthus (Asteraceae), ocorrentes na Serra do Cipó, MG, Brasil. Acta Botanica Brasilica, v.19, n.4, p.753-761, 2005. http://www. scielo.br/scielo.php?pid=S0102-33062005000400010\&script=sci_arttext

VILHALVA, D.A.A.; APPEZZATO-DA-GLÓRIA, B. Morfoanatomia do sistema subterrâneo de Callea verticillata (Klatt) Pruski e Isostigma megapotamicum (Spreng.) Sherff - Asteraceae. Revista Brasileira de Botânica, v.29, n.1, p.29-47, 2006. http://www.scielo.br/scielo. php? script=sci_arttext\&pid=S0100-84042006000100005\&lng $=$ en\&nrm=iso \&tlng $=\mathrm{pt}$

ZAIDAN, L.B.P.; CARREIRA, R.C. Germination ecophysiology of Cerrado seeds. Brazilian Journal of Plant Physiology, v.20, n.3, p.167181, 2008. http://www.scielo.br/scielo.php?script=sci_arttext\&pid=S1677$04202008000300002 \& \operatorname{lng}=$ en\&nrm=iso\&tlng=en 